\title{
A Study of Ideological and Political Education in Higher Vocational Colleges in We Media Era
}

\author{
Xuegan Wang \\ Jiangxi Technical College of Manufacturing 330095,China
}

Keywords: We Media; Higher Vocational College; ideological and political education

\begin{abstract}
For a long time, ideological and political education in Higher Vocational Colleges usually takes the mode of verbal and mental instructions which ignores to some extent students' specific needs and fails to satisfy them with its teaching effects. In the environment of We Media, ideological and political education in Higher Vocational Colleges has ushered new developments. This paper firstly analyzes the characteristics of We Media era, then explores the influence of We Media and lastly, proposes several perfection methods for Ideological and political education in Higher Vocational Colleges in We Media era.

Higher Vocational Colleges are important campaigns to cultivate high-quality and skilled talents. Because of the particularity of talent cultivation quality as well as prospective students, ideological and political education here seems to be quite important. In the mobile Internet era, the influence of We Media on college students' learning and life is increasing. At the same time, ideological and political education in Higher Vocational Colleges also has ushered new opportunities and challenges. Contemporary college students are active in thinking, always seeking novelty and wonder. Therefore, the topic that how to use We Media to guide students' ideological and political education is extremely important and worth urgent exploration.
\end{abstract}

\section{An Overview of Characteristics of We Media Era}

We Media which is also called personal media and citizen media specifically refers to a new type of media form by which civilian, private, universal communicators deliver all kinds of information through Internet. We Media platform includes WeChat, Micro-blog, headlines and so on, by which the transformation of "point to point" is realized. Everyone is able to deliver and propagate information. Its liberalized and personalized information dissemination and reception mode satisfy to a great extent the communicative needs of modern people.

In We Media era, its liberalization, popularization and facilitation match the diversity and personalization of college students' values, so more and more students are keen to use We Media. Compared with traditional media, in the We Media era, students' information interaction and exchange begin to show new features. Students turn to be communicators from media audience. Besides, their communication methods tend to be more independent, getting rid of any regulation or intervention, which is conducive to the cultivation of sense of responsibility as well as independence. Simultaneously, We Media era makes equal communication come true. College students are capable of interacting equally with the identity of common Internet citizens. This helps to enhance their consciousness of equality and then lead them to express voices, thoughts and ideas actively for various college affairs. In addition, the open characteristic of We Media also promotes the appearance of leaders among students to express opinions. Through We Media, these student leaders are able to enhance public influences by forms such as comment, chat and reprint. These methods can guide students' dynamic thoughts and communication about economy, politics and society etc., offering new development chances for Internet communication education. Overall, in We Media era, based on the features of We Media as well as new characteristics of higher vocational students, Internet interaction tends to be different, which produces great influences on ideological and political propaganda and education in Higher Vocational Colleges. ${ }^{[1]}$ 


\section{Analysis of Influence of We Media on Ideological and Political Education in Higher Vocational Colleges}

As college student groups in the new era, higher vocational students are characterized with a strong sense of curiosity and thirst for knowledge. We Media offers them with broad expression and cognition channels. Besides, it also provides indispensable knowledge such as new technologies, new concepts and new professional trends for vocational students. We Media has already integrated into students' learning and daily life. Therefore, as the carrier of ideological and political education in Higher Vocational Colleges, We Media has congenital advantages. Its popular feature applied in ideological and political education enables teaching to be more affinity and reduces sense of distance. Its personalization and popular characteristics transfer voice to the public and make itself a platform for public expression. Therefore, with such a strong power of influencing public opinions, We Media inevitably becomes a tool for ideological and political education. To put it more specific, compared with traditional media, We Media has brought brand new contents and modes for ideological and political education in Higher Vocational Colleges with its advantages and features. ${ }^{[2]}$ From the perspective of contents, We Media has brought huge amounts of information and powerful search function which offer more opportunities for the development of ideological and political education. In the view of modes, We Media has changed students' access to information and communication, effectively enhancing their autonomy to get information. Meanwhile, its immediacy, interactivity and personalization enable students to be more willing to participate and receive. Thus, ideological and political teaching can be more targeted.

The influence of continuous development and penetrating application of We Media on ideological and political education in Higher Vocational Colleges is a "double-edged sword". We Media has brought new opportunities for ideological and political teaching, but also new challenges. Characteristics of We Media like anonymity and fiction weaken students' moral easily that will elevate the difficulty of ideological and political teaching. Specifically, ideological and political education in We Media era confronts the following challenges. Firstly, the real-time and interactive features of We Media provides rich information and expression channels for students. While the entrance of complex and abundant information into students' sights challenges the mainstream social values. However, higher vocational students' competence to tell right from wrong needs to be improved. The absence of enough education and guidance will result into their fault values and cognitive deviation. Interference from We Media at any time brings great difficulty to traditional ideological and political education. It is easy for diversified communication and expression channels to produce regulatory bind areas. The current Internet public opinion monitoring and processing capacities still can not meet the broadcasting requirements of We Media. At the same time, diversified channels and contents of We Media also hinder ideological and political education. Higher vocational students are in the critical period of values formation. They are vulnerable to adverse influence from incorrect understanding of various cultures, thoughts and new born things. In addition, with the condition in which all kinds of ideological and cultural thoughts conflict, students will confront negative impacts from information that is uneven in quality. ${ }^{[3]}$ Therefore, ideological and political education in Higher Vocational Colleges needs to define challenges which are produced by diversified channels and forms. Moreover, We Media is featured by strong interactivity and sense of experience. Students are willing to accept new things, prefer to observe and think independently and like sharing as well as interaction. They repel the traditional one-way and authoritative teaching. Therefore, the traditional didactic ideological and political teaching can no longer adapt to their needs. Now, students are able to get information form multiple channels and the subjective relationship between teachers and students also has been changed greatly. In ideological and political education, teachers are the dominators no more. Students are bestowed with certain right to voice. Therefore, the problem that how to combine actively the ideological and political teaching with characteristics of We Media era to make education modes more adaptable is worth the most urgent dealing. 


\section{Perfection Methods of Ideological and Political Education in Higher Vocational Colleges in We Media Era}

In We Media era, Higher Vocational Colleges should perfect organizations and improve ideological and political working system. It will be conducive to promote the coordination among various related departments, bringing their superiority into full play and realizing cooperation. For example, the organization departments of Party Committees are suggested to make use of new media to strengthen the cultivation of Party Members and Applicant for Party Membership. The Propaganda Department of Party Committee is advised to integrate actively new media resources to promote broadcasting. The Communist Youth League is supposed to organize effectively all kinds of activities, such as speeches, lectures and reports and so on. Related activities will strengthen students' understanding of We Media and the cultivation of healthy consciousness of responsibility. It is also feasible to encourage cadres and instructors to enhance the application of WeChat and Micro-blog etc. to guide teachers to master new media application technologies, actively use new media to communicate with students and improve the attractiveness of ideological and political education. It is also necessary to guide staff related to ideological and political education to understand sufficiently the importance of We Media. They need to keep pace with the times, grasp its characteristics, actively accept and study We Media, continuously improve teaching contents and update teaching methods.

If We Media platforms are properly managed and instructed with features of assertion and style, it will win more students' preference, then broadcast positive energy and play a more active role in guiding positive public opinions. Therefore, Higher Vocational Colleges should actively establish We Media official platforms, arrange full-time staff to do work like maintaining We Media platforms information management and publishing. These measures are conducive to occupy the main camp of ideological and political education and leading students to learn national and Party conditions as well as history. Furthermore, it will be helpful to set up service We Media such as WeChat public platform to provide students with substantial guidance on volunteer activities, mental health and employment. Meanwhile, Students Primary Party Branches with backbone students and instructors is proposed to set up We Media platform and give full play to the ideological leaders. For example, Students Primary Party Branches and communities can set up WeChat public number and Micro-blog to enhance interaction. Besides, instructors and teachers' personal platforms like Micro-blog and headlines can stimulate management and interaction, strengthen the mastering of students' dynamic thoughts and in further carry out pertinent teaching. In We Media era, although new media enjoys a rapid development, the application scope of traditional media is shrinking gradually. When taking advantages of We Media, ideological and political education in Higher Vocational Colleges should draw on the experience of the traditional one and pay attention to the usage of campus medias like traditional newspapers, realizing their combination and contributing to the development of ideological and political education. ${ }^{[4]}$

With the help of We Media, ideological and political education in Higher Vocational Colleges are supposed to improve the pertinence of its won teaching by exploring actively teaching modes and contents that can adapt to students. Firstly, We Media contents must be rich and clearly classified. Teachers are able to enrich ideological and political learning contents with abundant We Media resources. By taking students' features of different majors into consideration, ideological and political classes will be more pertinent and they will be more willing to accept teaching. It is also necessary to keep contents effective. Teachers should avoid using outdated education contents since in We Media era, information is updated in a fast speed. Contents published on We Media platforms like WeChat, Micro-blog and so on should use a tone that is close to students but not bureaucratic. This will turn ideological and political education more intimate and personalized, satisfying students' needs of communication, entertainment and fragmented reading. Meanwhile, We Media also can deliver positive energy, promote main rhythm and imperceptibly effect students' values. Moreover, it is capable of penetrating the whole process of ideological and political teaching. For example, during the teaching of theoretical classes, teachers can let students know contents and 
questions to be discussed in advance. Then, students can carry out mutual discussion in class and deeper learning with We Media after class. ${ }^{[5]}$ In addition, colleges should make effective use of We Media to enhance practical teaching. Through We Media platforms such as WeChat and Micro-blog, more abundant social practices and new modes can be created. It is recommended to develop ideological and political education practices by making use of features of We Media. For example, centering on hot social events, teachers are suggested to guide students to debate and study. In this way, social practices are fused with Internet, enabling students to confront positively complex social conditions and cultivating their sense of responsibility.

The open and entertaining characteristics of We Media have a great influence on students' thoughts and values, therefore, the management and supervision of We Media platforms need to be strengthened. With the further application of We Media, it is necessary for Higher Vocational Colleges to enhance Internet safety supervision. To be specific, departments related to ideological and political education are suggested to enhance daily inspection and maintenance. Instructors are supposed to coordinate all monitors to be responsible for maintenance and management of We Media platforms. Meanwhile, it is feasible to cultivate some student Party Members and excellent cadres as the administrators. These measures will be conducive to the construction of three-dimensional management modes with multi-channels which can stimulate fully students' initiatives, enable them to invest more enthusiasm in management and constantly enrich management construction of We Media platforms. Simultaneously, it is advised to revitalize more teaching resources from students' perspective and give a full play to the ideological and political education function of We Media.

\section{Conclusion}

In a word, the appearance of We Media era updates the traditional teaching modes and contents of ideological and political education in Higher Vocational Colleges. However, in teaching practices, there are many problems existing in We Media supervision. Therefore, we should constantly conclude and practice during ideological and political education, make use of We Media platforms, give a full play to WeChat, Micro-blog etc, construct a new phenomenon within the fusion of reality and fiction, and then enhance comprehensively the effectiveness of ideological and political education in Higher Vocational Colleges.

\section{References}

[1]Liu Zhihong, Wang Yuxue. "Public Opinions Publishing": Exploration of New Media Application in Ideological and Political Education in Higher Vocational Colleges-Take Micro-blog Public Platform as An Example [J]. Intelligence, 2015 (25): 84-85.

[2]Yang Jiaozhen, Yan Ruili. A Study of Expanding Practical Teaching of College Ideological and Political Education by Making Use of Internet [J]. Journal of Guangdong Industry Technical College, 2013 (3): 129.

[3]Xia Yong. Construction of New Media Platforms of College Students' Ideological and Political Education [J]. Education Digest, 2015 (1): 278.

[4]Yuan Jingjin. Innovation of Ideological and Political Teaching in Higher Vocational Colleges from the Perspective of We Media [J]. Journal of Qiqihar Junior Teachers' College, 2017 (15): 174-175.

[5]Gong Yun. Innovated Mode of We Media Application in Ideological and Political Education in Higher Vocational Colleges [J]. High School Years, 2017 (15): 174-175. 